\title{
Assessment of Energy Sustainability in Statistical Regions of Latvia using Energy Sustainability Index
}

\author{
Dzintra SLIŠĀNE ${ }^{1 *}$, Gatis GAUMIGS²${ }^{2}$ Dace LAUKA ${ }^{3}$, Dagnija BLUMBERGA ${ }^{4}$ \\ ${ }^{1-4}$ Institute of Energy Systems and Environment, Riga Technical University, Azenes iela 12/1, \\ Riga, LV 1048, Latvia
}

\begin{abstract}
The Single Energy Sustainability Index combines three key sustainability indicators: environmental, social and economic. The use of indicators makes it possible to create an overall index that shows not only how green the region is, but also includes the wellbeing and economic situation of its population. The study uses a universal formula that is adapted to the case study of Latvia. The energy sustainability index formula combines 12 weighted indicators. The multi-criteria analysis method AHP was used to determine criteria weights for this purpose. Latvia's overall sustainability index was calculated at 0.48 and only the Riga region (0.65) exceeds the index value for Latvia as a whole. Using this sustainability development index, it is also possible to analyse possible future development scenarios for energy sustainability in Latvia and its regions. To assess the potential for future development and sustainability of regions in Latvia and other countries, it is necessary to continue the study.
\end{abstract}

Keywords - Analytic hierarchy process (AHP); economic aspects; energy sector; energy sustainability index; environmental aspects; social aspects; regions; sustainability

$\begin{array}{ll}\text { Nomenclature } & \\ I^{+} \mathrm{N}, i j & \text { Normalized value of the indicator with positive effects } \\ I_{\mathrm{N}, i j} & \text { Normalized value of the indicator with negative effects } \\ I_{\mathrm{A}, i j}^{+}, I_{\mathrm{A}, i j} & \text { Value of the specific " } i \text { " indicator } \\ I^{+}{ }_{\text {min, }, j}, I_{\text {min }, j} & i \text { - minimum value of its indicator in the regions analysed } \\ I^{+}{ }_{\text {max }, i j}, I_{\text {max }, i j} & j \text { - maximum value of its indicator in the regions analysed } \\ a_{\mathrm{jk}} & \text { Element A of the matrix }(j, k) \\ w_{j} & \text { Criteria weight vector } \\ I_{\mathrm{s}, j} & \text { Sustainability index } \\ I & \text { Energy sustainability indicator } \\ I_{\mathrm{s}, j} & \text { Index of individual aspect } \\ w_{\mathrm{s}} & \text { Individual aspect index weight }\end{array}$

* Corresponding author.

E-mail address: Dzintra.Slisane_1@rtu.lv 


\section{INTRODUCTION}

Sustainable development is one of the European Union's (EU) core challenges, more than 20 years since it was enshrined in the Treaty of Amsterdam as an overall EU policy objective. The EU defines sustainable development as a development based on balanced economic growth and price stability, a competitive social market economy aimed at full employment and social progress, and a high level of environmental protection and improving environmental quality [1]. As climate change rates rise, the EU has seen a need for more active action and developed a new strategy: The European Green Deal. The European Green Deal aims to make the European economy climate-neutral, not forgetting also the social and economic sustainability dimension: improving the quality of life of citizens by protecting the natural living environment of people [2], [3]. One of the four focal points of the European Green Deal is the energy sector. Energy production and use currently accounts for more than $75 \%$ of EU greenhouse gas emissions. Consistently, the energy sector is an essential point for climate change mitigation and the application of environmental policies in Latvia [4].

At the national level, Latvia's National Energy and Climate Plan 2021-2030 has been developed which sets out the basic principles, objectives and action lines for the country's energy and climate policy for the next ten years, considering long-term developments. "The long-term objective of the plan is to promote the development of a climate-neutral economy in a sustainable, competitive, cost-effective, safe and market-based way." Not only does the European Green Deal lead to sustainable development, but at the national level it also serves as a programming document that provides a way forward for sustainable development. To achieve the long-term objective, the intermediate objectives of promoting more efficient use of resources are identified. Reduce the consumption of fossil and unsustainable resources while introducing the use and availability of renewable and innovative resources for all groups of society. The plan also aims to stimulate research and innovation, which would contribute to the above-mentioned challenges. 12 action lines have been identified to achieve the objectives of the Action Plan and set out the energy and climate policy objectives and targets stemming from EU legislation. The planned national contribution to the national targets is expressed in five dimensions of the Energy Union.

1. Decarburization.

2. Energy efficiency.

3. Energy security.

4. Internal energy market.

5. Research, innovation and competitiveness.

At the national level, measures are being put in place to move the economy towards sustainable development [5]. Significant measures are envisaged to achieve targets, such as the use of liquefied natural gas (LNG) in transport and high-capacity wind park projects.

There are several ways in which energy production costs, such as atmospheric pollution costs, are internalized. Without the internalization of these costs, the unregulated market would lead to excessive use of fossil resources, energy producers would not have the initiative to choose renewable resources, and energy consumers have less initiative to increase energy efficiency. Similarly, one way of benefiting renewable energy is to internalize their external benefits. A tax on pollution, subsidies for renewable energy in the form of raw material prices, support from EU structural funds and other sources of funding are some of the possible measures to internalize external costs [6].

The literature contains examples of a variety of attempts to establish a common methodology for evaluating policy, economic or environmental measures, not only on the basis of their direct purpose and contribution, but also on the potential side effects and consequences they will have 
in the region's economy, and in terms of its social and environmental areas. An example is described in article [7], which describes the development of an energy sustainability index to assess energy policy in the US and to warn of the impending energy crisis in 2007 . The developed index included four groups of indicators: oil security (import, export, price, non-fossil transport \%, energy efficiency for transport fuel use), energy efficiency (energy intensity and energy consumption), reliability/security of electricity supply (natural gas import, price, and electricity tariff) and environmental quality ( $\mathrm{SO}_{2}$ and $\mathrm{CO}_{2}$ emissions from energy).

The Eurostat website provides information on the values of 17 Sustainable Development Goals and Indicators for Sustainable Development from UN 2030 Agenda in each of the Member States. One of these objectives is economically accessible and clean energy. At present, the EU's progress towards this objective is not clearly positive. The EU makes good progress in reducing the energy consumption of households in terms of final consumption and GHG emissions, as well as in relation to increased energy productivity and share of RES. However, in terms of energy dependency, progress is insufficient and final energy consumption figures are currently moving away from the EU target [8]. These indicators are applicable at the national level in Latvia as well, but development is not going smoothly throughout the country, for example, it is obvious that economic and social activities in Latvia are concentrated in Riga and its agglomeration. At the European Union level, one of the main initiatives focusing on regional support and involvement in achieving climate change objectives is the Covenant of Mayors. It aims to equip cities with the methodologies and tools needed to create the city's Sustainable Energy Action Plans. In Latvia, 24 cities, including Riga, have joined the pact, of which 21 cities submitted an action plan, the implementation of which is monitored. The Covenant of Mayors offers a broad and detailed range of sustainable energy indicators, but these indicators are not tailored to rural areas and focus directly on cities [9], [10].

The sustainability of energy in the context of regional and rural communities was examined in [11] using the Main Component Analysis (PCA - principal Component Analysis) method. For Haris Doukas et al. [11] energy sustainability index, 8 indicators were selected: population density, GDP energy consumption, population-to-population production of RES, population consumption of fossil fuels, RES electricity, RES heating, RES/fossil fuel electricity generation, and population-to-peak tourists. A similar division was used to calculate the Household sustainability index for heat generation [12]. Another example of using a composite index to assess sustainability can be found in [13], this article includes not only the economic, social and environmental dimensions, but also an institutional dimension that supports the other dimensions. Composite sustainability indexes have also been used for the assessment of energy systems [14], energy security [15] and energy production services [16]. Recently an overall index for measuring energy sustainability of various countries using integrated MCDM method analysing 35 countries including Latvia [17]. Therefore, we can safely assume that energy sustainability on the national level is a well analysed topic. Energy sustainability is topical also on the level of enterprises [18]. A review on sustainability indices and indicators as tools to energy issues has been made by Rafael Ninno Muniz et al. [19]. They compared Energy Indicators for Sustainable Development designed by the International Atomic Energy Agency (IAEA), Energy Indicators for Sustainable Development (EISD), Energy Development Index (EDI) by IEA, Multidimensional Energy Poverty Index (MEPI), Sustainable Energy Development Index (SEDI), Sustainable Development of Energy, Water, and Environment Systems Index (SDEWES), Regulatory Indicators for Sustainable Energy (RISE) and Synthetic Index of Sustainable Energy Development (SISED).

It is also noted that a selection of specific indicators can be adapted to suit specific local situation [20]. A clear understanding of the current situation about what is obtainable through sustainability indices can help achieving better energy sustainability. 


\section{Methodology for Developing a Single Energy Sustainability INDEX FOR REGIONS}

The Single Energy Sustainability Index combines three key sustainability indicator groups. The use of all three key aspects of sustainability - the environment, social and economic - allows for the creation of an overall index showing not only how "green" the region in question is, but also including the welfare and economic situation of its population.

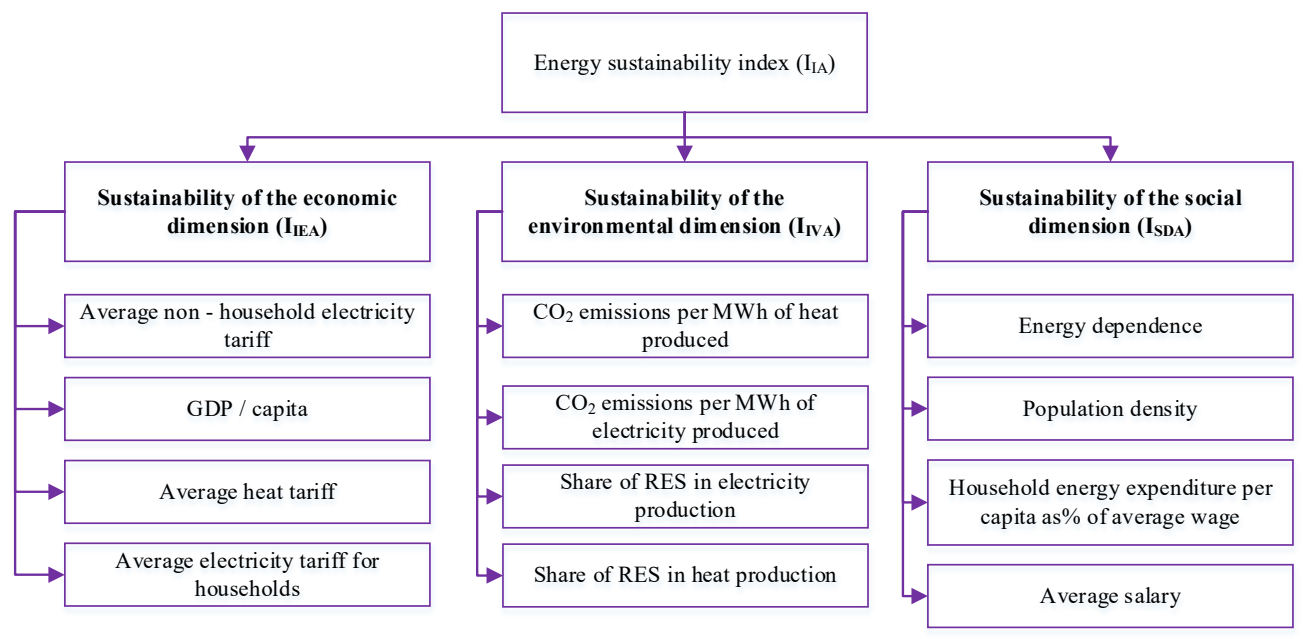

Fig. 1. Sustainable energy development index.

The energy sustainability index for regions was developed using similar steps as in the methodology used in this study [20] that explores the use of to the sustainable development index for a company demonstrated using a sample of Henkel companies. The index contains indicators that describe the sustainability of regions in the energy cut. These indicators are divided into three categories based on the aspects of sustainability (environmental, economic and social) (see Fig. 1).

Economic factors include indicators such as: average non - household electricity tariff, GDP per capita, average heat and electricity tariffs. In the environmental aspect category indicators are selected to describe the sustainability of the environmental dimension: $\mathrm{CO}_{2}$ emissions per $\mathrm{MWh}$ of heat and electricity produced, share of RES in electricity and heat production. Sustainability of the social dimension is assessed by energy dependency, population density, household energy expenditure per capita as \% of average wage, and average salary.

\subsection{Data used and Calculation of Indicators}

For the purpose of the study, the division of Latvia into statistical regions was used, as defined in the Cabinet of Ministers Regulation No 271 of 28 April 2004, "On the statistical regions of the Republic of Latvia and the administrative units contained therein" [21]. 
TABLE 1. ENERGY SUSTAINABILITY INDICATOR CALCULATION INPUT DATA

\begin{tabular}{|c|c|c|c|c|c|c|c|}
\hline & 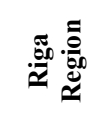 & 营 & 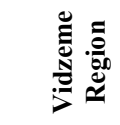 & 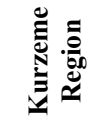 & 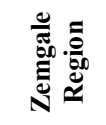 & 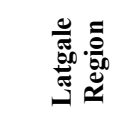 & $\underset{\frac{\pi}{2}}{\frac{\pi}{2}}$ \\
\hline \multicolumn{8}{|l|}{ Economic indicators } \\
\hline GDP/capita (2017), EUR & 22458 & 11726 & 8927 & 10282 & 8487 & 7164 & 13805 \\
\hline $\begin{array}{l}\text { Average electricity tariff end for non- } \\
\text { household users, EUR/kwh }\end{array}$ & 0.1832 & 0.1832 & 0.1832 & 0.1832 & 0.1832 & 0.1832 & 0.18 \\
\hline $\begin{array}{l}\text { Electricity tariff for households, } \\
\text { EUR/kWh }\end{array}$ & 0.157 & 0.157 & 0.157 & 0.157 & 0.157 & 0.157 & 0.16 \\
\hline Heat energy tariff, EUR/MWh & 44 & 54 & 58 & 55 & 50 & 54 & 52.42 \\
\hline \multicolumn{8}{|l|}{ Social indicators } \\
\hline $\begin{array}{l}\text { Average wages of citizens in } 2017 \\
\text { (net), EUR }\end{array}$ & 758 & 640 & 544 & 568 & 579 & 471 & 676 \\
\hline $\begin{array}{l}\text { Energy dependency (\% energy } \\
\text { imports) }\end{array}$ & $\begin{array}{l}44.06 \\
\%\end{array}$ & $\begin{array}{l}44.06 \\
\%\end{array}$ & $\begin{array}{l}44.06 \\
\%\end{array}$ & $\begin{array}{l}44.06 \\
\%\end{array}$ & $\begin{array}{l}44.06 \\
\%\end{array}$ & $\begin{array}{l}44.06 \\
\%\end{array}$ & $\begin{array}{l}44.06 \\
\%\end{array}$ \\
\hline Population density, people per $\mathbf{k m}^{2}$ & 2110 & 36 & 13 & 18 & 22 & 19 & 30 \\
\hline $\begin{array}{l}\text { Household expenditure on energy } \\
\text { resources per person } \% \text { of average } \\
\text { wages }\end{array}$ & $38 \%$ & $45 \%$ & $52 \%$ & $50 \%$ & $49 \%$ & $61 \%$ & $42 \%$ \\
\hline \multicolumn{8}{|l|}{ Environmental indicators } \\
\hline $\begin{array}{l}\mathrm{CO}_{2} \text { emissions from heat generation, } \\
\mathrm{tCO} / \mathrm{MWh}\end{array}$ & 0.1089 & 0.2118 & 0.1046 & 0.2944 & 0.1618 & 0.0588 & 0.1567 \\
\hline $\begin{array}{l}\mathrm{CO}_{2} \text { emissions from electricity } \\
\text { generation, } \mathrm{tCO}_{2} / \mathrm{MWh}(2016)\end{array}$ & 0.1049 & 0.1049 & 0.1049 & 0.1049 & 0.1049 & 0.1049 & 0.1049 \\
\hline Share of RES in heating, \% & $57 \%$ & $21 \%$ & $60 \%$ & $12 \%$ & $45 \%$ & $76 \%$ & $54.6 \%$ \\
\hline Share of RES in electricity supply, \% & $54 \%$ & $54 \%$ & $54 \%$ & $54 \%$ & $54 \%$ & $54 \%$ & $54 \%$ \\
\hline
\end{tabular}

$\mathrm{CO}_{2}$ emissions from heat generation are calculated using the emission factors given in Annex 1 to the Cabinet of Ministers Regulation No 42 of 23 January 2018 Methodology for calculating greenhouse gas emissions [22] and data on enterprise energy consumption compiled from the Air 2 reports of the Latvian Environment, Geology and Meteorology Centre (LEGMC) [23]. The calculation assumes the following efficiency of boilers:

- Heavy fuel - $95 \%$ [24];

- Diesel fuel - $85 \%$ [25];

- Natural gas - $94 \%$ [26];

- Liquefied gas - $94 \%[25]$;

- Coal - $77 \%$ [27];

- Worn-out tires $-70 \%$.

For liquid fuels, the emission factor and boiler efficiency are assumed to be equal to diesel emissions and boiler efficiency. The $\mathrm{CO}_{2}$ emissions from electricity generation for Latvia are the 
same, as it is not possible to separate the origin of electricity from each municipality. The value of $\mathrm{CO}_{2}$ emissions from electricity used to calculate the index was taken from the European Environment Agency database on emission intensity [28].

\subsection{Data Normalization}

In accordance with the [20] methodology, normalization of indicators will be carried out on the basis of whether the indicator has a positive or negative impact on sustainability. Positive impacts mean that higher values of this indicator indicate better relevance to sustainable development, for example, the highest possible values of the RES rate are desirable. An indicator with a negative impact is one that is expected to have minimal values, such as the amount of $\mathrm{CO}_{2}$ emissions.

Indicators with positive effects are normalized using the Eq. (1).

$$
I_{\mathrm{N}, j}^{+}=\frac{I_{\mathrm{A}, i j}^{+}-I_{\min , j}^{+}}{I_{\max , j}^{+}-I_{\min , j}^{+}}
$$

Indicators with negative effects are normalized using the Eq. (2).

$$
I_{\mathrm{N}, i j}^{-}=1-\frac{I_{\mathrm{A}, i j}^{+}-I_{\min , j}^{+}}{I_{\max , j}^{+}-I_{\min , j}^{+}}
$$

\subsection{Determination of the Weight of the Indicators}

The next step is the determination of the weights of the indicators, which are carried out using the multi-criteria analysis method AHP. The AHP method [29], [30] is suitable for determining the weights of the various criteria based on a comparison of the importance of the criteria (in this case indicators) carried out by the expert or expert group.

AHP method is based on a pairwise comparison matrix A, which reflects the decision-maker's choice of relative importance for each criteria in comparison with other criteria used in the study [30].

It is assumed that $a_{j k}$ denotes element $\mathrm{A}$ of the matrix $(j, k)$, if criteria $j$ and $k$ are equally significant $a_{y k}$ will be equal to $1\left(a_{j k}=1\right)$, if $a_{y k}=5$ criterion $\mathrm{j}$ is five times more important than the criterion $\mathrm{k}$, if $a_{y k}=9$ criterion $\mathrm{j}$ is absolutely more important than $\mathrm{k}$. Other possible $a_{y k}$ values between 1 and 9 are interpreted according to the above model.

To ensure the uniformity of the matrix data $a_{j k}=b$ automatically means that $a_{j k}=1 / b$ and matrix A diagonal value will be equal to 1 because the criterion will be compared to itself. When such a matrix is created, the elements of each column are divided by the sum of the elements of this column, thereby obtaining the $N$ elements of the normalized weighted matrix.

$$
\bar{a}_{j k}=\frac{a_{j k}}{\sum_{i=1}^{m} a_{j k}}
$$

The weight of the relative criteria is calculated as the average for each row of matrix $\mathrm{N}$. The criterion weight vector $w_{j}$ is calculated by summing up the value in each column and divided by the number of columns in $m$. 


$$
w_{j}=\frac{\sum_{i=1}^{m} \bar{a}_{j k}}{m}
$$

The weights of the indicators shall be determined separately for each group of indicators (economic, social and environmental).

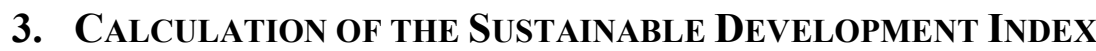

For each of the 3 indicator groups, an individual sustainability index is calculated by summing up the positive indicator for this group $I_{N, j i}^{+}$the products of the indicator weights $w_{j t}$ and subtracting from it the sum of the negative indicator $I_{N, j i}^{-}$and their weight $w_{i j}$.

$$
I_{s, j t}=\sum_{j i}^{n} W_{j} \cdot I_{N, j i}^{+}+\sum_{j i}^{n} W_{j} \cdot I_{N, j i}^{-}
$$

The Eq. (5) determined the weights of the indicators for each group of indicators separately.

TABLE 2. INDIVIDUAL WEIGHTS OF INDICATORS AND THEIR IMPACT (NEGATIVE/Positive EFFECT ON SUSTAINABILITY)

\begin{tabular}{lll}
\hline Indicators & Weight & $\begin{array}{c}\text { Positive /negative } \\
\text { impact }\end{array}$ \\
\hline Economic conditions & & \\
\hline GDP/capita (2017) EUR & 0.14 & + \\
Average electricity tariff for non-household end-users, EUR/kWh & 0.24 & - \\
Electricity tariff for households, EUR/kWh & 0.34 & - \\
Heat energy tariff, EUR/MWh & 0.28 & - \\
\hline Social aspects & & \\
\hline Average wages of citizens in 2017 (on hand), EUR & 0.39 & + \\
Energy dependency (\% energy imports) & 0.13 & - \\
Population density, people per km ${ }^{2}$ & 0.06 & + \\
Household expenditure on energy resources per person $\%$ of average wages & 0.42 & - \\
\hline Environment aspects & & \\
\hline $\mathrm{CO}_{2}$ emissions from heat generation, $\mathrm{tCO}_{2} / \mathrm{MWh}$ & 0.25 & - \\
$\mathrm{CO}_{2}$ emissions from electricity generation, $\mathrm{tCO} / \mathrm{MWh}(2016)$ & 0.25 & - \\
Share of RES in heating, $\%$ & 0.25 & + \\
Share of RES in electricity supply, $\%$ & 0.25 & + \\
\hline
\end{tabular}

The Energy Sustainability Index is calculated as the weighted sum of the individual indexes of each group Eq. (6).

$$
I=\sum I_{s, j} \cdot w_{s}
$$




\section{ENERGY SUSTAINABILITY INDEX IN STATISTICAL REGIONS OF LATVIA}

Using the methodology described above, the Energy Sustainability Index was calculated. First, by calculating separately the Energy Sustainability Index for the Environment, Economic and Social Aspects and then merging them into a common energy sustainability index. In addition, it was assumed that the weights of the economic indicator in the final index were 0.4 and the weight of the other two indicators was 0.3 (according to the methodology, the sum of the weights of all components of the index should be equal to 1). The calculated sustainability index is shown in the form of columns in Fig. 2.

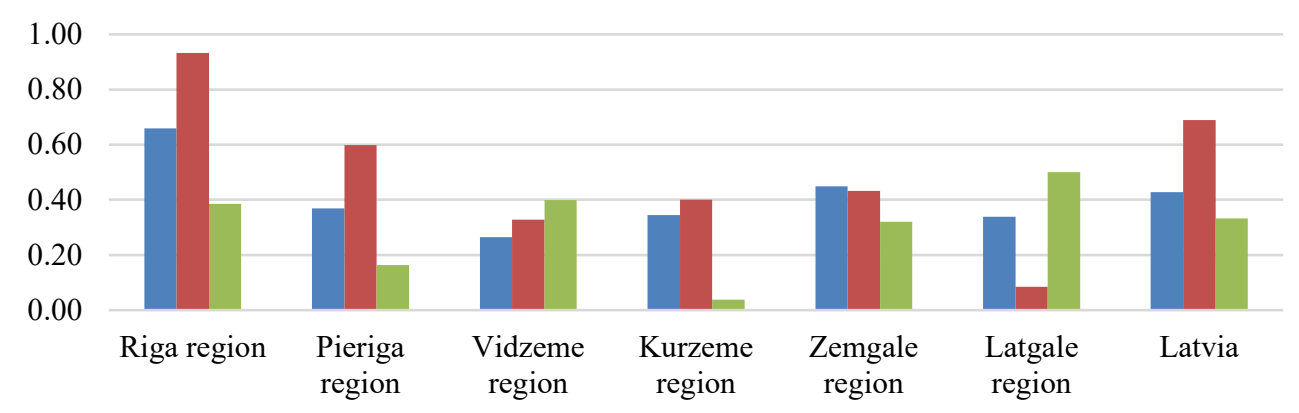

- Energy sustainabilty economic aspect

Energy sustainabilty social aspect

Energy sustainability environmental aspect

Fig. 2. Energy sustainability indicator and its components in Latvia's statistical planning regions.

The energy sustainability index for Latvia has a total value of 0.48 . It is marked with the line in Fig. 3. We can see that only the statistical planning region index of Riga exceeds the value of the index for Latvia as a whole.

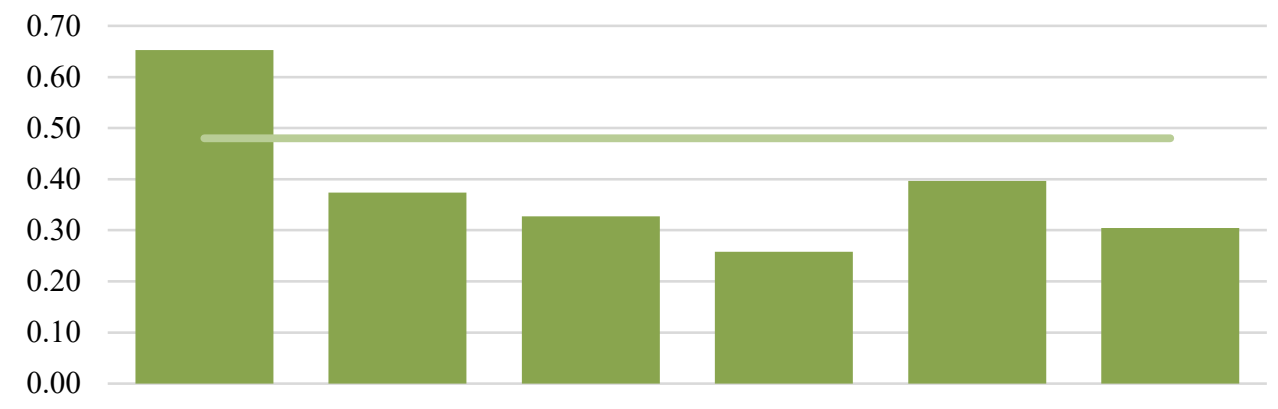

Riga region Pieriga region Vidzemes region Kurzemes region Zemgales region Latgales region

$\longrightarrow$ Latvia

Fig. 3. Energy sustainability index in Latvia and statistical planning regions. 


\section{Discussion}

The Single Energy Sustainable Development Index combines three key sustainability indicators: environmental, social and economic. The use of these indicators makes it possible to create an overall index that shows not only how "green" the region is, but also includes the well-being and economic situation of its population.

Assessing the results, it is apparent that the energy sustainability index for the Riga region exceeds the average of Latvia. The results depend on the indicators selected and the available data in the regional breakdown. When assessing the results from the point of view of the existing indicators, Kurzeme can be considered as the less "green" region. The energy sustainability index gives priority not only to regions but also to the targeted groups of indicators.

The results obtained reflect the current situation, since the indicators selected are based on an analysis of data in 2017. Using this sustainability development index, it is also possible to analyse the development of Latvia and regions on the development side of different scenarios. The method applied should also be used for the analysis and cross-comparison of other countries. In order to assess the potential for future development and sustainability of regions in Latvia and other countries, it is necessary to continue the study.

\section{ACKNOWLEDGEMENT}

This research is funded by the Latvian Council of Science, project "Blind spots in the energy transition policy (BlindSpots)", project No. lzp-2018/2-0022.

\section{REFERENCES}

[1] United Nations. Transforming our World: the 2030 Agenda for Sustainable Development. New York: UN, 2015.

[2] European Comission. What is the European Green Deal? 2019. [Online]. [Accessed 01.02.2020]. Available: https://ec.europa.eu/info/sites/info/files/european-green-deal-communication_en.pdf

[3] Iddrisu I., Bhattacharyya S. C. Sustainable energy development index: A multi-dimensional indicator for measuring sustainable energy development. Renewable and Sustainable Energy Reviews 2015:50:513-530. https://doi.org/10.1016/j.rser.2015.05.032

[4] Blumberga D., et al. Energy, Bioeconomy, Climate Changes and Environment Nexus. Environmental and Climate Technologies 2019:23(3):370-392. https://doi.org/10.2478/rtuect-2019-0102

[5] Prodanuks T., Blumberga D. Methodology of municipal energy plans. Priorities for sustainability. Energy Procedia 2018:147:594-599. https://doi.org/10.1016/j.egypro.2018.07.076

[6] Štreimikienė D. Review of internalization of externalities and dynamics of atmospheric emissions in energy sector of Baltic States. Renewable and Sustainable Energy Reviews 2017:70:1131-1141. https://doi.org/10.1016/j.rser.2016.12.017

[7] Brown M. A., Sovacool B. K. Developing an 'energy sustainability index'. Interdisciplinary Science Reviews 2007:32(4):335-349. https://doi.org/10.1179/030801807X211793

[8] European Commission. How has the EU progressed towards the SDGs? Eurostat [Online]. [Accessed 02.2020]. Available: https://ec.europa.eu/eurostat/web/sdi/key-findings

[9] Covenant of Mayors for Climate \& Energy [Online]. [Accessed 06.02.2020]. Available: https://www.covenantofmayors.eu/en/

[10] Marquez-Ballesteros M.-J., et al. Measuring urban energy sustainability and its application to two Spanish cities: Malaga and Barcelona. Sustainable Cities and Society 2019:45:335-347. https://doi.org/10.1016/j.scs.2018.10.044

[11] Doukas H., et al. Assessing energy sustainability of rural communities using Principal Component Analysis. Renewable and Sustainable Energy Reviews 2012:16(4):1949-1957. https://doi.org/10.1016/j.rser.2012.01.018

[12] Kuznecova I., et al. Calculation Framework of Household Sustainability Index for Heat Generation. Energy Procedia 2017:113:476-481. https://doi.org/10.1016/j.egypro.2017.04.043

[13] Cîrstea S. D., et al. Evaluating Renewable Energy Sustainability by Composite Index. Sustainability 2018:10(3):811. https://doi.org/10.3390/su10030811 
[14] Nakthong V., Kubaha K. Development of a Sustainability Index for an Energy Management System in Thailand. Sustanability 2019:11(17):4587. https://doi.org/10.3390/su11174587

[15] Narula K., et al. Sustainable energy security for India: An assessment of the energy supply sub-system. Energy Policy 2017:103:127-144. https://doi.org/10.1016/j.enpol.2017.01.001

[16] Gómez-Camacho C. E. Ruggeri B. Energy Sustainability Analysis (ESA) of Energy-Producing Processes: A Case Study on Distributed $\mathrm{H}_{2}$ Production. Sustainability 2019:11(18):4911. https://doi.org/10.3390/su11184911

[17] Altintas K., et al. An Extended GRA Method Integrated with Fuzzy AHP to Construct a Multidimensional Index for Ranking Overall Energy Sustainability Performances. Sustainability 2020:12(4):1602. https://doi.org/10.3390/su12041602

[18] Prashar A. Towards sustainable development in industrial small and Medium-sized Enterprises: An energy sustainability approach. Journal of Cleaner Production 2019:235:977-996. https://doi.org/10.1016/j.jclepro.2019.07.045

[19] Muniz N. R., et al. Tools for Measuring Energy Sustainability: A Comparative Review. Energies 2020:13:2366. https://doi.org/10.3390/en13092366

[20] Krajnc D., Glavi P. A model for integrated assessment of sustainable development. Resources, Conservation and Recycling 2005:43(2):189-208. https://doi.org/10.1016/j.resconrec.2004.06.002

[21] Cabinet of Ministers. Regulation No 271 of 28 April 2004. On the statistical regions of the Republic of Latvia and the administrative units contained therein. (in Latvian)

[22] Cabinet of Ministers. Regulation No 42 of 23 January 2018. Methodology for calculating greenhouse gas emissions. (in Latvian)

[23] LEGMC. Pprocedure for completing the data of the national statistical report "No.2-Air - Report on air protection". (in Latvian)

[24] Ghersi F. Hybrid bottom-up/top-down energy and economy outlooks: A review of IMACLIM-S experiments. Frontiers in Environmental Science 2015:3:74. https://doi.org/10.3389/fenvs.2015.00074

[25] Aycateknik. Boilers [Online]. [Accessed 05.02.2020]. Available: https://www.aycateknik.com/kotel-otoplenija-namazute (in Latvian)

[26] Bosh. Condensing type gas appliances [Online]. [Accessed 25.08.2020]. Available: https://www.junkers.lv/files/Kondensacijas_tipa_gazes_iekartas_LV_(TT_1903_LV)_LV.pdf (in Latvian)

[27] Solitherm. Heating furnace [Online]. [Accessed ${ }^{-}$05.02.2020]. Available: http://www.sadzivessantehnika.lv/assets/doc/Solitherm_info.pdf

[28] European Environment Agency. $\mathrm{CO}_{2}$ emission intensity [Online]. [Accessed 03.01.2020]. Available: https://www.eea.europa.eu/data-and-maps/daviz/co2-emission-intensity-5\#tabgooglechartid_chart_11_filters=\{"rowFilters"\%3A \{\}$\% 3 \mathrm{~B}$ "columnFilters"\%3A $\{$ "pre_config_ugeo $\% 22 \% 3 \mathrm{~A} \% 5 \mathrm{~B} \% 2$ 2European Union (current composition)"\%3B"Latvia\%22\%5D\%7D\%7D

[29] Saaty, T. L. Analytical Hierarchy Process: Planning, Priority Setting, Resource allocation. New York: McGraw-Hill, 1980.

[30] Samal R. K., Kansal M. L. Sustainable development contribution assessment of renewable energy projects using AHP and compromise programming techniques. 2015 International Conference on Energy, Power and Environment: Towards Sustainable Growth (ICEPE) 2015:1-6. https://doi.org/10.1109/EPETSG.2015.7510096 